УДК $821.161 .2-31$

Веретюк T. В., кандидат філологічних наук, викладач кафедри української і світової літератури Харківського національного педагогічного університету імені Г. С. Сковороди

\title{
ЖІНОЧІ ТИПИ В РОМАНІ ІГОРЯ МУРАТОВА «У СОРОЧЦІ НАРОДЖЕНИЙ»
}

Ця стаття присвячена вивченню проблеми становлення людини у складних життєвих обставинах та розгляду другорядних жіночих образів роману, а також тих подій, щзо впливали на становлення та утвердження характерів ичих образів, розкриваються умови формування персонажів такого рівня.

Ключові слова: проблема, приклад, тип, характер, час, пристосуванство.

Эта статья посвящается изучению проблемы становления человека в трудных жизненных обстоятельствах и рассмотрению второстепенных женских образов романа, а также тех событий, которые влияли на становление и утверждение характеров этих образов, раскрываются условия формирования персонажей такого уровня.

Ключевые слова: проблема, пример, тип, характер, время, приспособленчество. 
This article dedicates to the problems of human being developing in difficult circumstances and considers secondary women images in the novel, and also those events, that influence on characters forming. The conditions to form the characters are presented too.

Keywords: problem, example, type, time, character, adapting.

Проблема становлення жінки, iï прагнення до самоактуалізації та особистісного зростання $є$ темою багатьох наукових студій і художніх творів. На сьогодні «жіноче питання» більше розглядається 3 точки зору феміністичного підходу до ролі жінки в соціумі або як жертви в її стосунках 3 чоловіками [Кукуленко-Лук'янець 2010:547].

Значення жінки в сучасному суспільстві, реалізація їі материнського потенціалу та здатність до самоактуалізації постають об’єктами аналізу в працях А. Менегетті, А. Чекалиної, Т. Андрєєвої, О. Пастушенко, О. Мірошниченко та інших. Серед класиків психологічної науки темі розкриття фемінного потенціалу особистості присвячені, зокрема, роботи 3. Фройда, К. Юнга, Е. Фрома [Кукуленко-Лук'янець 2010:547]. В українському літературознавстві до аналізу феміністичного дискурсу звертались В. Агеєва, Н. Білоус, Т. Гундорова, Л. Демська-Будзуляк, Н. Зборовська, Г. Кошарська, А. Новиков, О. Омельчук, О. Переломова, Т. Ткаченко, С. Філоненко та інші, що свідчить про особливу актуальність цієї проблематики.

Проте в наукових дослідженнях жінка мало репрезентується як творець або як суб'єкт творення. Здатність жінки до креативності або до руйнування детермінується багатьма глибиннопсихологічними чинниками. Водночас поза увагою дослідників залишається проблема здатності жінки до творення свого життєвого простору [Кукуленко-Лук’янець 2010:547]. Крім того, у переважній більшості випадків літературознавці аналізують образ жінки-матері, жінкидружини, жінки-берегині родинного вогнища, натомість образ жінки як багатогранний феномен - не досить досліджене на сьогодні явище. Спробуймо проаналізувати цю проблематику на матеріалі роману Ігоря Муратова «У сорочці народжений», що побачив світ у київському видавництві «Радянський письменник» 1965 року. 
Як відомо, у 1960-ті роки з’являються романи гостро поставленої соціально-громадянської проблематики («Правда i кривда» М. Стельмаха, «День для прийдешнього» П. Загребельного, «Хвилі» Ю. Збанацького), романи поетично-узагальнених, філософських «обертонів» («Тронка», «Циклон» О. Гончара), романи та повісті про працю й життя тогочасної людини 3 особливим акцентом на морально-етичних проблемах («Жила на світі вдова», «Свіже повітря для матері» I. Муратова, «Людина живе двічі» Ю. Шовкопляса, «Сільські вчителі» і «Шкільний хліб» Є. Гуцала, «Крапля крові» Ю. Мушкетика, «Лісова Гута» П. Дорошка) [Новиченко 1976:83]. Роман «У сорочці народжений» належить до останнього типу. I саме в цих творах 3'являються нові типи жіночих образів. Принаймні героїні роману Муратова постають напрочуд реалістичними й неоднозначними. Утім, свого часу критики й літературознавці, звертаючи увагу на тематику й проблематику таких творів письменника, як «Жила на світі вдова», «Свіже повітря для матері», «У сорочці народжений», на їхні композиційні особливості та засоби психологізму, не присвятили дослідженню образів жінок жодної спеціальної студії, згадуючи про героїнь цих творів лише принагідно.

Тож мета нашої розвідки полягає у розгляді другорядних жіночих образів роману «У сорочці народжений» (головний жіночий образ цього твору Варю - ми вже розглядали в статті «Опозиційні образи: роман Ігоря Муратова “У сорочці народжений”» [Веретюк 2010], власне кажучи, - у виявленні основних тенденцій, що спонукають героїнь до побудови або деструкції свого життєвого простору.

Прикладом у житті для головного героя твору Федора стає його тітка Надія Василівна - людина розумна, тактовна й роботяща, якій він завдячує своїми життєвими принципами. Про ऑiі зовнішність автор згадує лише принагідно, зображуючи іï переважно в молодості: «дрібне ряботиння - сліди перенесеної у дитинстві віспи - не змогло зіпсувати ї̈ відкритого обличчя 3 високим розумним чолом і вдумливими сірими очима» [Муратов 1983:17]. 
Надія Василівна ставиться до себе 3 особливою вимогливістю, намагається максимально об'єктивно оцінювати і власні вчинки, i вчинки оточуючих. Часом іï об’єктивність вражає своєю нетерпимістю до вад інших, зокрема, рідних людей, яскравим прикладом чого є розмова Надії Василівни 3 братом:

- Не тільки розумникам, Надю, хочеться жити на світі. Дурні, вони теж свої права виставляють...

- Для дурнів і для розумних рівності до кіния світу не жди, - відрубала вона, з огидою поглядаючи скоса на його розпухлу від горілки червону пику [Муратов 1983:36].

Надія Василівна нетерпима до пияцтва. Вона переживає за брата, чий син при живому батькові росте як сирота (мати хлопчика померла раніше), хоча добре розуміє, що допомогти братові не в змозі - звідси іï намагання вберегти племінника від долі батька-п’янички.

Прагнення Надії Василівни зробити із Федора людину й підвищена вимогливість до себе не полишають іï до самої смерті. «Що я таке зробила за своє життя? - питає себе раптом Надія Василівна. - Малувато, мабуть, коли боюся померти... Не була Надія Василівна на громадянській війні. Жениха на ній втратила, цуе правда. А сама із зброєю в руках проти ворогів не билася. I чужнх дітей не навчала. I рідних не виховувала. Самого тільки Федька... Відколи Федькова доля стала ї̈ власною долею, і на хвилинку не покидало ї̈ неспокою. Спочатку хвилювалася, чи пощуастить замінити йому матір. Трохи згодом сушила собі голову - чи прогодує його у голодні роки. Потім - чи зуміє $з$ ц̧ього чубатого иибеника виховати справжню людину, тобто таку, щзо заробляла б на хліб чесним трудом, а не різними витребеньками. А коли Федько вже закінчив робітфак і працюював на будові, то нова турбота прийшла: щзоб не зв'язав свого життя з легковажною жінкою» [Муратов 1983:243].

Надія Василівна досить суворо оцінює своє життя, їй хочеться його продовжити, але не заради себе самої, а, знову ж таки, заради Федорового блага: «... ̈̈й ... хочеться скинути оті десять рочків. Вона б щуе зробила щуось, 
принесла б якусь користь. I внучку свою, Лізочку, ... допомогла б виховати ...» [Муратов 1983:245].

Як бачимо, Надія Василівна все своє життя присвятила своєму племіннику й тодішній владі, якій вона стовідсотково довіряла, оскільки саме вона зробила час життя Надії Василівни - своїм часом. У цьому вбачаємо данину письменника тодішньому політичному режиму.

Іншою подає автор матір Варі Раїсу Іонівну, яка протягом свого життя прагнула прилаштуватися 3 максимальною зручністю. У думках вона часто порівнювала своє життя до революції і після неї, і час дореволюційний здавався їй кращим хоча б тому, що він був минулий, а минуле змінити неможливо, воно не вимагає ніяких дій, тому він для неї прийнятніший за сучасність, яка передбачає дію заради покращення свого життя. Діяти, працювати Раїса Іонівна не була налаштована, а честолюбство мала велике: «Нічого в них не відібрала революція, навіть будинок залишили бабиі, не було за чим і жалкувати. А всетаки щуось пішло, хай навіть не своє, але таке, без чого $і$ Райсине життя знебарвилось, утратило милу серцеві звичність.

Навіть те, що за старих часів (тепер говорили - “за старого режиму”) вона була компаньйонкою при сварливій самотній княгині, символічно наближало ї̈ до заповітної межі, за якою кінчалися плебейські злигодні $i$ починався шляхетний комфорт. I коли б навіть справдилася Миколина (чоловікова) мрія $i$ з нього став би концертний соліст, все одно вона тепер не могла б мати справжньої насолоди з иісї удачі. Бо місие дружини знаменитості посеред фраків - одне, а в юрбі тілогрійок - щось інше» [Муратов 1983:40].

Прагнення будь-що пристосуватися до будь-яких умов стало для Раїси Іонівни першочерговим порівняно з усіма іншими тривогами й прагненнями. Їй здавалося, що час зв'язує іiі з чоловіком, позбавляє іï свободи, хоча саме втеча 3 рідного Харкова від свого чоловіка й доньок до Сухумі з коханцем Георгієм назавжди позбавила iї свободи, адже в Сухумі вона повністю залежала від коханця, який, як каже вона сама, «то дорікав мені, щцо витрачаю багато 
грошей, то буквально закидав коштовними подарунками. A потім $i$ зовсім зник... Ні. Вірити мужчинам у наш час може тільки патентована ідіотка...» [Муратов 1983:222]. Коли ж через багато років вона повертається до Харкова, то залежить від милості Варі та їі родини:

- Невже у рідному місті для мене не знайдеться якогось кутка?... I, зрештою, я маю тут у Харкові рідну доньку...

- Оие ж про доньку я й хочу сказати. Чи варто вам пристосовуватись до молодої родини?.. [Муратов 1983:226].

Ще одним важливим моментом стає поведінка Раїси Іонівни під час війни. Перебуваючи в евакуації разом із молодшою донькою й онукою, вона фактично втратила людську подобу, іiі стан передається лише через Варин погляд збоку: «I як тільки можна було так опуститися?... - Hу, війна, ну, евакуачія, жахлива тіснява, але щоб з ранку до вечора ходити нечесаною? У засмальиьованім халаті та спущених дірявих панчохах? I ие після їі хваленого сухумського життя, коли мати, якщо вірити їй, одягалася за останньою модою і доводила до божевілля усіх знайомих грузинів!» [Муратов 1983:265].

Щоправда, автор звертає нашу увагу на ту обставину, що єдиною людиною, якій Варя могла б розказати про «свої компроміси з совістю», була Раїса Іонівна. Та цього не трапилося, оскільки Варя не може відкрити свою душу перед людиною, яку вона не бачила майже двадцять років, а тому й ставиться до неї зверхньо: «Не сердься, ми надто довго з тобою не бачилися, щэоб вимагати одна від одної уваги і відвертості...» [Муратов 1983:172].

Можна зробити висновок, що в образі Раїси Іонівні письменник змальовує тип жінок пасивних, індиферентних, схильних довірятися долі й не докладати вольових зусиль для отримання необхідних змін у житті [КукуленкоЛук'янець 2010:554], адже Раїса Іонівна до кінця свого життя так і жила в родині доньки, оскільки нічого кращого доля ій не запропонувала.

Ще одним цікавим другорядним образом є образ доньки головних героїв Лізочки, хибність життєвих настанов якої дуже непокоїла батьків, адже ці настанови полягали не в прилаштуванні життя до певних скрутних обставин, 
чим почасти виправдовувала свої дії Раїса Іонівна, не в боязні перед сильними світу цього (модель поведінки матері), а просто в тому, що Лізочка прагнула саме найпростішого, найлегшого, «неординарного», на iї погляд, способу життя. Така настанова була породжена вихованням Лізочки, яким займалися переважно Раїса Іонівна та Варя. Суттєвий вплив справив на неї і іï хлопець Савочка. Варто зауважити, що в романі відсутнє зображення Лізочки в дитинстві, автор лише говорить, що в подружжя народилася дівчинка. Тож читач уперше зустрічає Лізочку вже студенткою театрального інституту.

Несамостійність іiі суджень була настільки очевидна, що це дозволило Федору (батькові) дати їй ось таку характеристику: «Лізочко, донечко, звернувся до неї Федір несподівано ніжно. - Сторонні можуть подумати, щзо ти - нігілістка. А ти ж у мене ніяка не нігілістка. Ти просто- папуга» [Муратов 1983:356]. Федір не міг сердитися на доньку, яка бездумно повторювала чужі слова, виправдовуючи це бажанням бути оригінальною у висловленнях та почасти захопленням ідеєю легкого, безтурботного життя.

Автор звертає увагу на той момент, що задовго до гострої розмови між Федором i Лізочкою батько дівчини впевнився в тому, що його донька налаштована на якесь виняткове життя, на піднесення над загалом. Проти таких настроїв він завжди боровся на роботі, але в родині не зміг утримати дружину від того, щоб вона віддала Лізочку вчитися до театрального інституту, адже за ії красивими словами ховалося звичайне пристосуванство й небажання працювати по-справжньому:

- По-перше, мені легше буде з іспитами, бо там у мами знайомство, а по-друге, я не збираюся бути, як ти, звичайним учителем

- А ти сподіваєшся стати надзвичайною актрисою?..

- Татусю, не сміши мене. Тепер усі прагнуть чого-небудь такого... [Муратов 1983:320].

Лізочка прагнула вступити до інституту на пільгових умовах і свої вчинки та прагнення пояснювала тенденціями часу, фактично повторюючи долю матері, але, на відміну від неї, Ліза не соромилася висловлювати такі 
думки вголос. Аналіз образу Лізочки доводить, що вона є типом жінки 3 полігамною психологією, яка розбиває міф про другорядне призначення жінки [Кукуленко-Лук'янець 2010:551]. Варто наголосити, що такий тип жінки, як правило, є породженням міста.

Отже, у романі «У сорочці народжений» Ігор Муратов майстерно змальовує другорядні жіночі образи. Образи Раїси Іонівни та Лізочки автор наділив лише фемінними рисами, а маскулінні характеристики, які передбачають активність, цілеспрямованість, наполегливість, прагматизм, раціоналізм, фактично повністю відсутні. Обидві героїні $є$ досить пасивними особистостями, нездатними до вольових вчинків та прийняття рішень. Їхній життєвий шлях визначають байдужість та індиферентність. Натомість Надія Василівна намагається будувати власний життєвий простір, у якому вона б почувалася щасливою і задоволеною долею (це пояснює іiї відмову вийти заміж, присвяту свого життя племіннику тощо). У неї справді відсутня деструктивність, але й повноцінного творення не відбувається.

\section{БІБЛІОГРАФІЯ}

Веретюк 2010 - Веретюк Т. Опозиційні образи: роман Ігоря Муратова «У сорочці народжений» / Т. Веретюк. // Вісник Луганського національного університету імені Тараса Шевченка: Філологічні науки. - Частина I. - 2010. № 4 (191). - C. 110-117.

Кукуленко-Лук’янець 2010 - Кукуленко-Лук'янець I. Психологічний образ жінки в українській літературі / I. Кукуленко-Лук’янець // Проблеми сучасної психології. - 2010. - Вип. 8. - С. 546-554.

Муратов 1983 - Муратов I. Твори: У 4-х т. Т. 3 / Упоряд. Н. БілецькаМуратова; приміт. К. Балабухи. - К., 1983. - С. 6-357.

Новиченко 1976 - Новиченко Л. Український радянський роман (Стислий нарис історії жанру) / Л. Новиченко. - К., 1976. - 132 с. 